\title{
Hypolipidemic Effect of Caffeic Acid Isolated From Arctium Lappa Cultivated In Iraq, in Hyperlipidemic Rat Model.
}

Mohammed A. Taher ${ }^{*}$, Dhuha A. Abdul- Hussain ${ }^{* *}$, Huda F. Hasan ${ }^{* * *}, 1$, Zena M. Fahmi $^{* *}$, Oday K. Luaibi ${ }^{* * * *}$ and Mezaal G. Ali ${ }^{* * * * *}$

\footnotetext{
* Department of Clinical Laboratory Science, College of Pharmacy, University of Baghdad, Baghdad, Iraq. ** Department of Pharmacognosy and Medicinal Plants, College of Pharmacy, University of Baghdad, Baghdad,Iraq. *** Department of Pharmacology and Physiology, College of Veterinary Medicine, University of Baghdad, Baghdad,Iraq. **** Department of Veterinary Internal and Preventive Medicine, College of Veterinary Medicine, University of Baghdad, Baghdad,Iraq.

***** Ibn-Alnafes Hospital-Ministry of Health, Baghdad, Iraq.
}

\section{Abstract}

The goal of the extant revision was to explore the influence of caffeic acid (CA) extracted from Arctium lappa $L$. on lipid profile and histology of aorta in rats . Analytical study demonstrated a high percentage of both chlorogenic and caffeic acid in the $80 \%$ methanol extract of the aerial parts (leaves and stems) of Arctium lappa L. from the family Asteraceace. Hypolipidemic activity of caffeic acid was studied against cholesterol induced hypercholesterolemia in Wistar albino rats for thirty days. Rats were separated into normal group (A), hypercholesterolemic positive controller group (B). While, the rest three groups $(\mathrm{C}, \mathrm{D}$ and $\mathrm{E})$ attended as hypercholesterolemic trial groups. Caffeic acid was given verbally at doses of $20 \mathrm{mg} / \mathrm{kg}$ body mass in Collection (C), $40 \mathrm{mg} / \mathrm{kg}$ in Collection(D) then $20 \mathrm{mg} / \mathrm{kg}$ in collection (E) after two weeks of administration of cholesterol induced hypercholesterolemia. There was an obvious histological improvement of changes induced by hypercholesteremia in aorta. Furthermore, using (CA) at $20 \mathrm{mg}$ after 2 weeks of feeding on cholesterol rich diet led to a important decline $(\mathrm{P}<0.05)$ in serum whole cholesterol levels in compassion with the control and cholesterol rich diet group. Moreover, There was a great improvement in the histology results convinced by the high cholesterol gorgeous diet, which can partly be attributed to an antioxidant activity of (CA).

Keywards: Arctium lappa, Caffeic acid, Hypolipidimic, Hypercholesterolemia.

$$
\begin{aligned}
& \text { تأثير حامض الكافيك المعزول من نبات الارقطيون المزروع في العراق على تخفيض نسبة } \\
& \text { دهون الام في نموذج الجرذان مفرطة الدهنية. }
\end{aligned}
$$

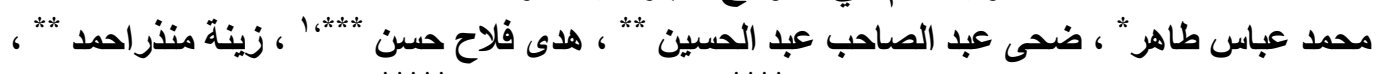

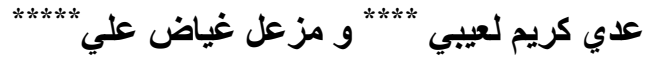

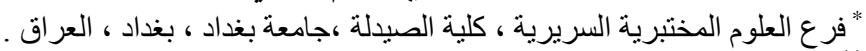

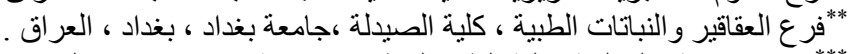

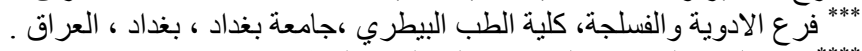

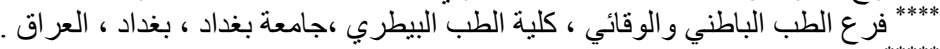

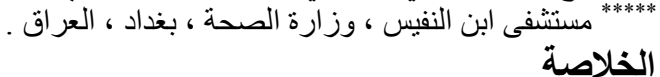
Intoduction

In the last few years great importance has been given to illnesses associated with high levels of blood cholesterol, plasma triglycerides with atherosclerosis and ischaemic heart disease. Treatment of hyperlipidaemia is preferably dietary

${ }^{1}$ Corresponding author E-mail: dr.hudaalqaraghuli@yahoo.com

Received: 23/8/ 2014

Accepted: 16/2/2015 
accompanied by other natural regimens.

Drug therapy was reversed for the more intractable conditions ${ }^{(1,2)}$. Natural products has a beneficial phytochemical compound named caffeic acid (3,4- dihydroxy cinnamic acid), it occurs regularly as the quinic acid ester, chlorogenic acid, it is an important ordinary dietary phenolic complex originate in plants which is an anti-oxidant. depressant the creation of leukotrienes which are complicated in immune-regulation, infection and sensitivity ${ }^{(3,4)}$. Over the previous period, plant medication has develop a theme of worldwide prominence, making an influence on both biosphere fitness and global trade. Curative plants stay to production a central heroine in the healthcare organization of large scopes of the world's populace. This is chiefly factual in emerging kingdoms, where plant medication has a extended and continuous past of usage ${ }^{(5)}$. Currently used hypolipidemic drugs are associated with so many adverse effects and withdrawal is associated with rebound phenomenon and this phenomenon referred to the appearance or recurrence of signs that were either lacking or measured while attractive a medication, but seem when that similar medication is discontinued, or concentrated in quantity. In the situation of recurrence, the strictness of the signs is often inferior than pretreatment levels, which is not seen with herbal preparations ${ }^{(6)}$. Plant parts or plant extract are sometimes even more potent than known hypolipidemic drugs, this indicates that the research has stopped with just reporting the effect of plant derivate and the findings are not translated into clinical research ${ }^{(7)}$, taking these finding forward is mandatory to develop new drugs in this area, hence further research into identifying the active principle, conducting preclinical studies and if possible clinical studies is needed ${ }^{(8)}$. More than 70 medicinal plants have been documented to have significant hypolipidemic action. Throughout the latter period, an upsurge in the use of remedial plants has been detected in metropolitan regions of advanced states. Curative plants show a major part in hypolipidemic activity. Advantages of herbal medicines reported are effectiveness, safety, affordability and acceptability ${ }^{(8-9)}$.

\section{Materials and Methods Arctium lappa plant}

Cultivated aerial parts in Arctium lappa were collected from the department of the medicinal plants, College of Agriculture, University of Baghdad.

\section{Method of extraction}

The authenticated plant parts were cleaned, dried in shade and exposed to maceration to catch rough powder. The indelicately powdered was extracted with methanolic alcohol in Soxhlet device. The plant was vaporized to wetness under vacuity and dried out in void desiccators .The residue stored in a refrigerator at $2-8{ }^{\circ} \mathrm{C}$ for use in the subsequent work ${ }^{(10)}$.

\section{Method of separation}

The separation and purification of caffeic acid carried out using a combination of two or more chromatographic techniques.HPLC analysis was carried out by (Water/Ireland) in the department of pharmacognosy, College of pharmacy, University of Baghdad. HPLC conditions for caffeic acid:

-Mobile phase:

A: water $0.2 \%$ formylic acid;

B: acetone-nitrile to Methanolic acid $(60: 40 \mathrm{v} / \mathrm{v})$.

-Column: C18 4.6mm X $250 \mathrm{~mm}$.

-Detection: UV - detector at $280 \mathrm{~nm}^{(11)}$.

While the separation of caffeic acid was achieved by preparative thin layer chromatography (PTLC) in the traveling phase (ethyl acetic acid - ethanolic acid water, 5 to 1 to $5, \mathrm{v} / \mathrm{v} / \mathrm{v}$ ) in room heat. Then detected under UV light ${ }^{(12)}$.

\section{Animals and diet}

Twenty five fit mature Wistar albino rats weigh up (250-300 gm) were recycled in the extant study. Rats were got from a laboratory animal household/ Pharmacy College/ University of Baghdad. Experiments were achieved between March and April-2014. Animals were sited in coops exposed to persistent environment circumstances. Method of preparing the diet of high cholesterol was conducted by mixing 1 gram of cholesterol per kilogram of body weight $(\mathrm{gm} / \mathrm{kg}$ ) with normal diet of animals. Caffiec acid was given orally to animals at a doses of $20 \mathrm{mg} / \mathrm{kg} /$ day and $40 \mathrm{mg} / \mathrm{kg} / \mathrm{day}$. animals were separated to (4) equal collections ( 5 rats in every one) upon the following design:

Group (A): control (normal) that were fed normal nutrition.

Group (B): Rats were given great cholesterol nutrition for 30 days.

Group (C): Rats were given $20 \mathrm{mg} / \mathrm{kg} /$ day of caffeic acid besides high cholesterol diet.

Group (D): Rats were given $40 \mathrm{mg} / \mathrm{kg} /$ day of caffeic acid besides great cholesterol diet.

Group (E): Rats were given $20 \mathrm{mg} / \mathrm{kg} /$ day of caffeic acid after two weeks of high cholesterol diet.

* Cholesterol (Biochemical) BDH Chemicals Ltd Poole England. 


\section{Blood samples}

Five at $2-8^{\circ} \mathrm{C}$ for analysis. milliliters $(5 \mathrm{~mL})$ of whole blood was drawn by heart puncture from each animal of all experimental groups after thirty days. The sample was transferred into plan tube, left at room heat for $15 \mathrm{~min}$. for clotting, then put in centrifuge at 3000 r.p.m for $15 \mathrm{~min}$., and finally serum was separated and preserved in a disposable tube and refrigerated

\section{Biochemical parameters}

Serum concentrations of tri-glyceride (TG), whole cholesterols (TC), height densities lipo-proteins-cholesterols (HDL-C) were sedate via usage kits from Bio Merieux, France. All procedures were followed according to the instructions of the manufacturer and rendering to Lipid Study Clinics protocols ${ }^{(13)}$. Low density lipoproteins of cholesterol was premeditated via usage of the method of Friedewald et al. ${ }^{(14)} \mathrm{TC}-\mathrm{HDL}-$ $\mathrm{C}-\mathrm{TG} / 5$. This formula is applicable when serum TG level is less than $400 \mathrm{mg} / \mathrm{dl}$.

\section{Histopathological Examination}

Animals were ansthetized by cervical dislocation. Aortic arches were stable in $10 \%$ formol, and surrounded in wax of paraffin; 5 micrometer-thick units $(\mu \mathrm{m}$-t sections) were marked according to conventional methods, including Hematoxylin and $\operatorname{Eosin}(\mathrm{H}$ and $\mathrm{E})$. In addition, special stains were used to fix the

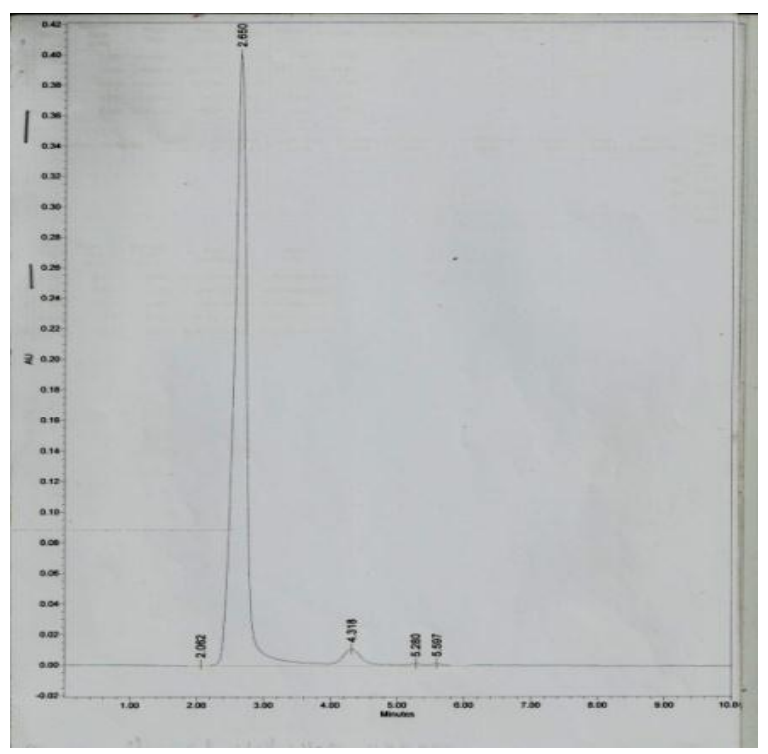

Figure (1): HPLC chromatogram of Caffeic acid std.(Left one) and plant extract sample with high peak of caffeic acid at $\left(\mathbf{R}_{\mathrm{t}} \mathbf{2 . 7 1}\right)$ identical to the reference standard( Right one).

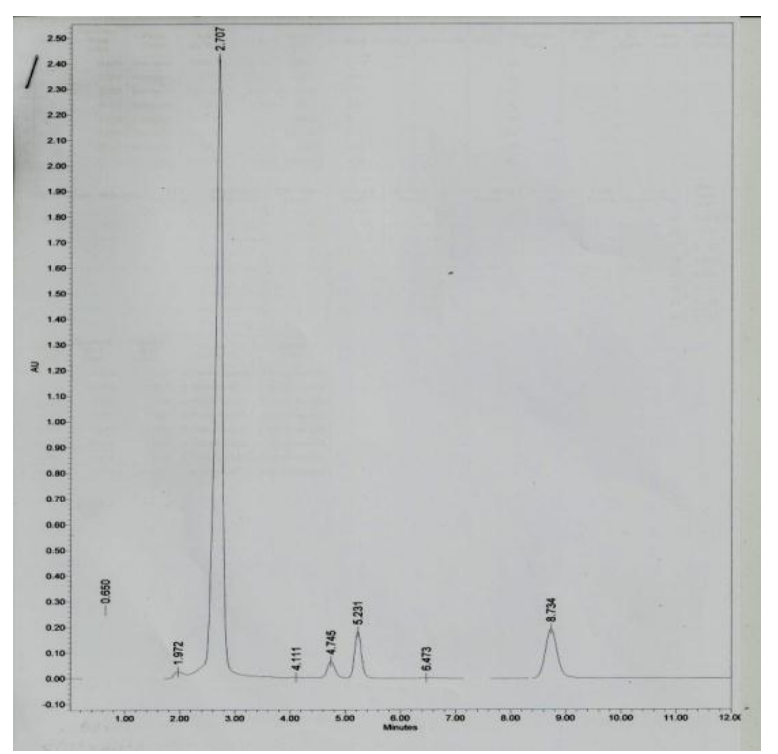

slides as VanGieson's and Masson trichrome(a mixture of picric acid and acid fuchsin, which manufactured by American country) .

Determination of atherosclerotic area by intima-media thickness (IMT) was conducted using calibrated ocular lens divided into millimeter $(\mathrm{mm})$ for each histological section of the stained aorta with $\mathrm{H}$ and $\mathrm{E}^{(15)}$.

\section{Arithmetical analysis}

Arithmetical analysis was complete by consuming the statistical analysis system SAS ${ }^{(16)}$. Consequences were uttered as mean \pm regular deviances (mean $\pm \mathrm{SD}$ ). One method ANOVA-test was taken to compare limits in altered studied collections. P standards $\mathrm{P}<$ 0.05 were reflected statistically important.

\section{Results}

\section{Chromatographic results} constituents in the sample was low and since the chemical tests and thin layer chromatography(TLC) were not enough to identify them. Therefore, HPLC was used to identify and provide a lot of information about the contents of the plant sample. In (figure 1) HPLC chromatogram of the plant sample gave us a high peak of caffeic acid at retention time $\left(R_{t}\right.$ 2.71) which is identical to the reference standard. From the area under the peak we calculated the percentage of caffeic acid in crude extract about $0.176 \mathrm{mg} / \mathrm{ml}$.
Concentration of the active phytochemical 


\section{Effects on serum lipid profiles}

Table -1 revealed that whole cholesterols (TC), Tri-glycerides (TG), Low densities lipo-protein L.D.L and Very Low densities lipo-protein (V LDL) of group given cholesterol rich diet (group B) showed important increase $(\mathrm{P}<0.05)$ as compared with normal group, in adding the High density lipoprotein (HDL) in group B showed important decrease $\mathrm{P}<0.05$ as related with normal group. (TC), (TG), (LDL) and (V LDL) in collections $\mathrm{C}, \mathrm{D}$ and $\mathrm{E}$ displayed important decrease $\mathrm{P}$ $<0.05$ as comparison with collection $\mathrm{B}$. while the HDL in collections $\mathrm{C}, \mathrm{D}$ and $\mathrm{E}$ exhibited important increase $\mathrm{P}<0.05$ as comparison with group B.

The collection given $20 \mathrm{mg}$ of CA after 2 weeks showed the best significant decline in serum total cholesterol $\mathrm{p}<0.05$ comparison with the normal group and other preserved collections (C and D). All treated group indicated no important change $\mathrm{p}<0.05$ in VLDL- cholesterol compared with control. LDL/ HDL ratio in group given cholesterol rich diet increases considerably $\mathrm{P}<0.05$ as comparison with normal rats.

Table(1): Effects of different doses of caffeic acid on lipids profiles in rats nursed on normal nutrition rich with high dose of cholesterol.

$* \mathrm{P}<0.05$ important differences from the normal group.

\begin{tabular}{|c|c|c|c|c|c|c|}
\hline Groups & $\begin{array}{c}\text { T.Cholestero } \\
\text { I M g/ d L }\end{array}$ & $\begin{array}{c}\text { tri- } \\
\text { glyceride } \\
\text { M g/d L }\end{array}$ & $\begin{array}{c}\text { H.D.L - } \\
\text { Cholesterol. } \\
\text { M g/ d L }\end{array}$ & $\begin{array}{l}\text { L.D.L- } \\
\text { Cholest. } \\
\text { Mg/dL }\end{array}$ & $\begin{array}{c}\text { V.L.D.L- } \\
\text { Choleste } \\
\text { rol. } \\
\text { Mg/ dL }\end{array}$ & l.D.l /H.D.l \\
\hline $\begin{array}{c}\text { A } \\
\text { Control }\end{array}$ & $\begin{array}{c}116.1 \pm \\
4.12\end{array}$ & $\begin{array}{c}101.13 \pm \\
35.37\end{array}$ & $\begin{array}{l}72.46 \pm \\
2.62\end{array}$ & $\begin{array}{c}23.4 \pm \\
4.62\end{array}$ & $\begin{array}{l}20.22 \pm \\
7.07\end{array}$ & $\begin{array}{l}0.32 \pm \\
0.052\end{array}$ \\
\hline $\begin{array}{c}\text { B } \\
\text { Cholest. } \\
\text { rich diet }\end{array}$ & $\begin{array}{l}176.05 \pm \\
35.57 *\end{array}$ & $\begin{array}{l}135.5 \pm \\
75.49^{*}\end{array}$ & $\begin{array}{l}51.85 \pm \\
7.75^{*}\end{array}$ & $\begin{array}{c}37.1 \pm \\
13.67^{*}\end{array}$ & $\begin{array}{l}27.1 \pm \\
15.09^{*}\end{array}$ & $\begin{array}{l}0.69 \pm \\
0.17^{*}\end{array}$ \\
\hline $\begin{array}{c}\text { C } \\
\text { Cholest. } \\
\text { with } 20 \mathrm{mgC} \\
\text {.A. }\end{array}$ & $\begin{array}{l}95.52 \pm \\
10.14 \mathrm{a}\end{array}$ & $\begin{array}{l}105.1 \pm \\
21.83 \mathrm{a}\end{array}$ & $\begin{array}{l}48.77 \pm \\
4.34 * \mathrm{a}\end{array}$ & $\begin{array}{l}25.7 \pm \\
10.55 \mathrm{a}\end{array}$ & $\begin{array}{c}21.02 \pm \\
4.36 \mathrm{a}\end{array}$ & $\begin{array}{c}0.52 \pm \\
0.22 * a\end{array}$ \\
\hline $\begin{array}{c}\text { D } \\
\text { Cholest. } \\
\text { with } 40 \mathrm{mg} \\
\text { C.A. }\end{array}$ & $\begin{array}{c}112.64 \pm \\
14.08 \mathrm{a}\end{array}$ & $\begin{array}{l}72.35 \pm \\
16.11 * a\end{array}$ & $\begin{array}{l}61.6 \pm \\
5.76 \mathrm{a}\end{array}$ & $\begin{array}{c}26.56 \pm \\
8.61 \mathrm{a}\end{array}$ & $\begin{array}{l}14.47 \pm \\
3.22 \mathrm{a}\end{array}$ & $\begin{array}{c}0.58 \pm \\
0.099 * \mathrm{a}\end{array}$ \\
\hline $\begin{array}{c}\mathbf{E} \\
\text { Cholest. } \\
\text { with } 20 \mathrm{mg} \\
\text { C.A. after } 2 \\
\text { weeks. }\end{array}$ & $\begin{array}{c}85.82 \pm \\
10.49 * a b\end{array}$ & $\begin{array}{l}84.62 \pm \\
17.70 * \mathrm{a}\end{array}$ & $\begin{array}{l}47.47 \pm \\
5.87 * a\end{array}$ & $\begin{array}{c}22.56 \pm \\
8.79 \mathrm{a}\end{array}$ & $\begin{array}{c}15.79 \pm \\
4.22 \mathrm{a}\end{array}$ & $\begin{array}{c}0.4 \pm \\
0.21 \mathrm{ab}\end{array}$ \\
\hline
\end{tabular}

a: $\mathrm{P}<0.05$ important differences from group $\mathrm{B}$ between column numbers.

b: $\mathrm{P}<0.05$ important differences from group $\mathrm{C}$ and group $\mathrm{D}$ between column numbers. 


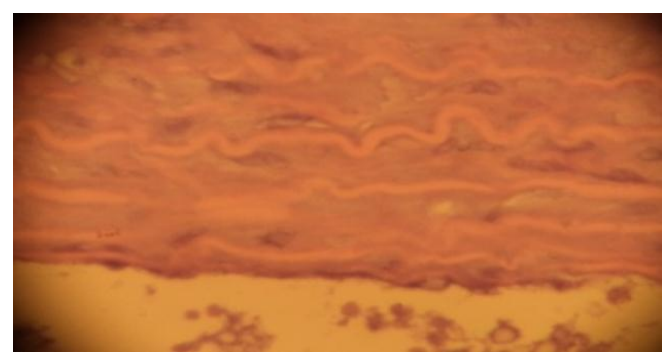

Figure (1): Group A- Histological section in aorta of control rat showed normal aorta tissue (H and E.X400).

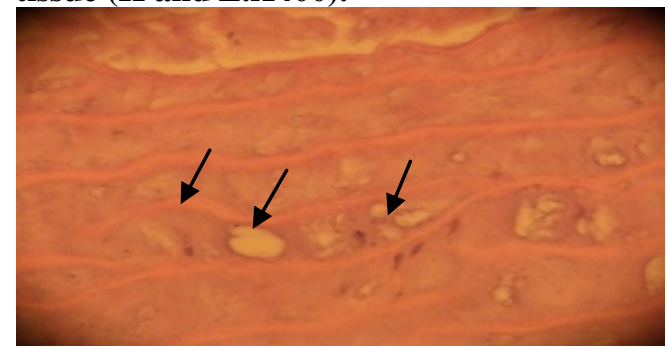

Figure (2): Group B- Histopathological section in aorta of rat given high cholesterol diet for 30 days showed degradation of elastic fiber and hyper enlargement due to infiltration of fat droplet between tunica media of aorta (H and E.X400).

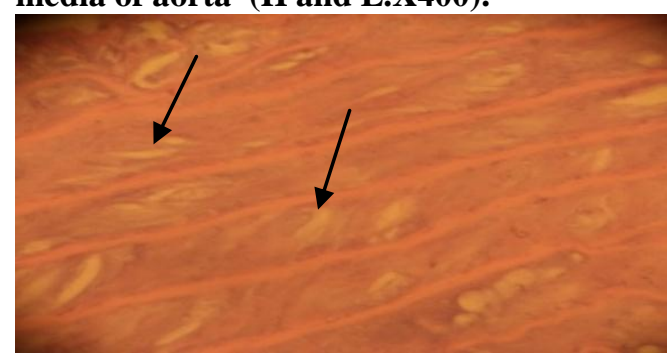

Figure (3):Group C- Histopathological section in aorta of rat given high cholesterol diet and treatment by caffeic acid 20 $\mathrm{mg} / \mathrm{kg} /$ day for 30 days showed decrease of fat droplet between elastic fiber of tunica media of aorta ( $\mathrm{H}$ and E.X400).

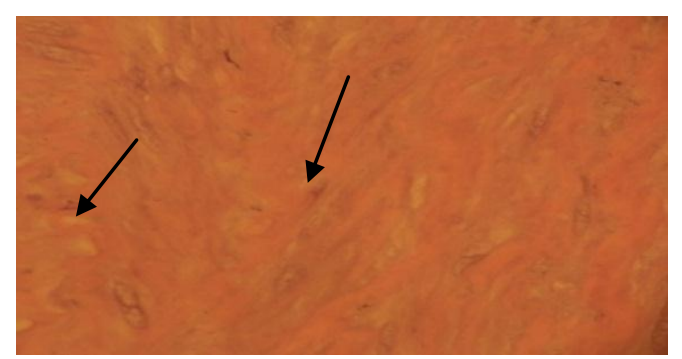

Figure (4):Group D- Histopathological section in aorta of rat given high cholesterol diet and treatment by caffeic acid 40 $\mathrm{mg} / \mathrm{kg} /$ day for 30 days showed decrease size of tunica media of aorta due to disappear of fat droplet (H and E.X400).

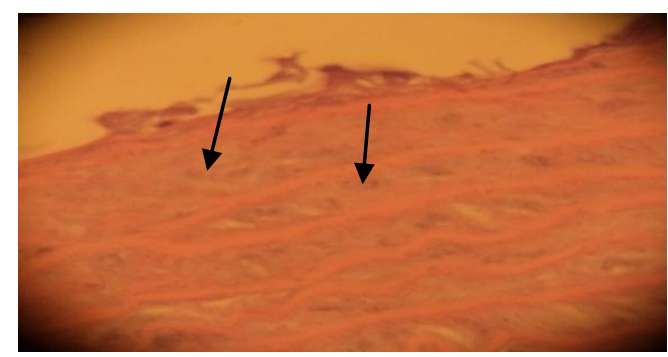

Figure (5):Group E- Histopathological section in aorta of rat given high cholesterol diet for 30days, and treatment by caffeic acid $20 \mathrm{mg} / \mathrm{kg} / \mathrm{day}$ after 2 weeks showed decrease in the size of tunica media and return to normal shape (H and E.X400).

\section{Discussion and Conclusion}

The results In table -1- of groups given diet rich with cholesterol and treated with 20 and $40 \mathrm{mg} / \mathrm{kg}$ of caffiec acid could be attributed to the activity of CA in decreasing serum total cholesterol levels in rats, in addition to any organic anion that competes with acetate can reduce the input of acetyl CoA and block the first step in cholesterol synthesis and Benzalbutyric acid (hypolipidemic drug ) impairs cholesterol and fatty acids synthesis by blocking acetylation of coenzyme $\mathrm{A}$, The similarity in chemical structure of $\mathrm{CA}$ with $\beta$ Benzylbutyric acid may suggest similar mechanism of action, this result agreement with result reported by Bowman and Rand ${ }^{(17)}$. Moreover, many investigational and scientific studies are established the atherosclerosis and circumstances disposing to atherosclerosis like hypercholesterolemia, increase in pressure and patient with great smoke are related with augmented vascular creation of radical oxygen species (18). There are another studies agreement with this result reported by Nardini , et al ; Yuchi, and Kimura ${ }^{(19,20)}$.

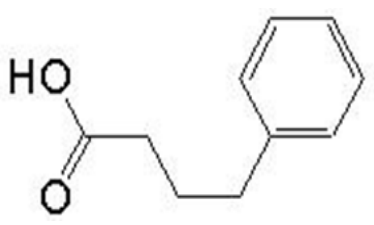

$\beta$-Benzylbutyric acid (21).<smiles>O=C(O)/C=C/c1ccc(O)c(O)c1</smiles>

Caffeic Acid ${ }^{(22)}$. 
The influence of Caffeic acid at the TGcholesterols and VLDL-cholesterol might be attributed to CA decrease tri-glyceride creation by decrease the countenance of both (three hydroxyl three methy-glutary coenzyme a reductase) and glycerol three phosphate acyltransferase in the liver by arrangement of adenosine mono phosphate activated kinase ${ }^{(23)}$. while that increase of HDL-cholesterol, in all study groups treated with caffeic acid might be indicated that doses of CA may have beneficial effect on HDL-cholesterol, by its effect as anti-lipid oxidation and suggested that CA lead to diminish oxygen species, and thus reduces DNA from impairment, which could be important in the regulation of liver function, this result agreement with result recorded by Codrington, et al $^{(24)}$.

The result of ratio of LDL/HDL in cholesterol rich diet group agreement with result reported by Danie, et al ${ }^{(25)}$, who found the low protein density/ high protein density percentage with Apo-lipoproteins, apolipoprotein B/ apo-lipoprotein A1 fraction require a solid forecasters of coronary of artery diseases. The group treated with $20 \mathrm{mg}$ of CA after 2 weeks of feeding with cholesterol showed best improvement in the atherogenic index ratio (LDL/HDL) evidenced by better histopathological findings, this might be attributed to antioxidant activity of CA which inhibit the degeneration of cholesterols in low protein density, lead to decrease the creation of froth cell that give to atherosclerotic plaque, this results supported by Viuda, et al ${ }^{(26)}$. Further study is needed to test the Arctium lappa containing CA to confirm the beneficial hypolipidimic effect of this medicinal plant Arctium lappa ${ }^{(27)}$.

In conclusion the Arctium lappa has benficial effect in lowering lipid associated with improvement in histological changes occurred due to hyperlipidemia, the best group was that treated with $20 \mathrm{mg}$ of CA after 2 weeks of feeding with cholesterol rich diet, in which the tunica media return to normal shape.

\section{Acknowledgements}

I would like to acknowledge Dr. Saged Auda Mohammad; head of the medicinal plants department College of Agriculture, University of Baghdad for identification of Arctium Lappa plant.

\section{References}

1. Maninder K., Kiranjeet K., Gurdeep K. B., Gurpreet S. S., Roopan S., Effect of felodipine on the serum lipid profile of patients with hypertension. Indian Journal of Clinical Biochemistry, July 2000; 15(2): 63-67.
2. Cui K, Luo X, Xu K, Ven Murthy MR. Role of oxidative stress in neurodegeneration: recent developments in assay methods for oxidative stress and nutraceutical antioxidants. Prog Neuropsychopharmacol Biol Psychiatry 2004; 28:771-799.

3. Goce D., Brock W. J.. Lipaemic samples: Effective process for lipid reduction using high speed centrifugation compared with ultracentrifugation. Biochemia Medica 2011;21(1):86-94.

4. Olanow C.W: A radical hypothesis for neurodegeneration. Trends Neurosci 1993; 16:439-444

5. Zhang HY, Tang XC: Huperzine B, a novel acetylcholinesterase inhibitor, attenuates $\mathrm{H} 2 \mathrm{O} 2$ induced injury in $\mathrm{PC} 12$ cells. Neurosci Lett 2000; 292:41-44.

6. Amit G, Vandana S, Sidharth $M$. Hyperlipidemia: An Updated Review. Inter $\mathbf{J}$ of Biopharma and Toxicol Res 2011;1:81-89.

7. Dhaliya S.. A, Surya A. S, Dawn V. T., Dr. Betty C., Dr. Arun K, Dr. Sunil C. A review of hyperlipidemia and medicinal plants. Int.J.A.PS.BMS .2013; Vol.2.(4) :219-237.

8. Priyanka V., Physiochemical and Phytochemical analysis of eclipta alba. Int j pharm bio sci, 2013; 4(3): 882 .

9. Chang H. J., Hee R. J., Gwi N. C., Dae O. K., Uk L. and Ho J. H. Neuroprotective and anti-oxidant effects of caffeic acid isolated from Erigeron annuus leaf. Chinese Medicine 2011; 6:25.

10. Trease and Evans, Pharmacognosy, chapter 3,Principles related to the commercial production, $16^{\mathrm{TH}}$ Edition, 2009, P:22-76.

11. Xiaoying Z., Haoke Z., Liang G. Determination of Arctiin and ArctigeninContents in Arctium Tomentosum Mill By HPLC Method, EJournal of Chemistry 2011; 8(1):372-376.

12. Stahl E. Thin Layer Chromatography Hand Book, $2^{\text {nd }}$ edition 1999.

13. Lipid Research of Laboratory Operations. DHEW ; 1975: 85-286.

14. Friedewald WT, Levy RI, Fredrickson DS. Estimation of the concentration of lowdensity lipoprotein cholesterol in plasma, without the preparative ultracentrifuge. Clin Chem 1972; 18: 499- 502.

15. Holman, R. L.; McGill, H.C. ; Strong, J.P. and Geer, J.C.: Techniques for studding atherosclerotic lesions. Lab. Invest. 1958; 7: 42-47.

16. SAS Institute, I. S.A.S Users Guide, Version 8.1. Cary, NC. 2000 
17. Bowman B.C and. Rand M.J.Textbook of Pharmacology (EDs.). $2^{\text {nd }}$ ed,Blackwell Scientific Publ.London.1984; 28-37.

18. Carney RM, Blumenthal JA, Catellier DE, Johan DF: Oxidative stress, antioxidant, vitamins, and atherosclerosis, from basic research to clinical practice.Herz. 2003;28(7):628-638.

19. Nardini, M., F. Natella, V. Gentili, M. Di Felice, and C. Scaccini.. Effect of caffeic acid dietary supplementation on the antioxidant defense system in rat: An in vivo study. Arch. Biochem. Biophys. 1997; 342(1):157-160.

20. Yuchi, S., and J. Kimura. Patent-Japan Kokai Tokkyo-61 40, 763. Chem Abstr.1986; 104:213296.

21. Thomas K. , Angewanti Chemie, 1979 ;18 ( 1): 1 - 90 .

22. Boerjan, W.; Ralph, J. and Baucher, M.. "Ligninbiosynthesis". Annual Review of Plant Biology. 2003; 54: 519-46.

23. Chung C. L.' Ting T. O., Hui P. H. andChau J. W.The inhibition of oleic acid induced hepatic lipogenesis and the promotion of lipolysis by caffeic acid via up-regulation of AMP-activated kinase .2013;55:122-199.

24. Codrington, A. M. ; Hales, B. F. and Robaire, B.: anti lipid oxidation of caffeic acid. 2007; 10-1095.

25. Daniel J., Rader H., Michael D., H., Richard.J., Caplan B. and John S. Pears Lipid and Apolipoprotein Ratios: Association with Coronary Artery disease and effects of Rosuvastatin Compared with Atorvastatin, Pravastatin, and Simvastatin. American Journal of Cardiology. 2003; 91 (5A), 20C-24C.

26. Viuda-M. M., FernándezL. J. and. PérezJ.A Pomegranate and its Many Functional Components as Related to Human Health, 2010; 22: 10-43.

27. Fabricia S. P., Ana L. R., João E. C., Mary A. F. and Heidi J.K., Antioxidative and In vitro antiproliferative activity of Arctiu $m$ lappa root extracts, 2011;24: 11-25. 